\title{
ON THE ISSUE OF CRIMINAL LIABILITY FOR VIOLATION OF THE RIGHTS TO GENDER IDENTITY AND SEXUAL ORIENTATION
}

\author{
S.S. KOVALOVA, PhD (Law), \\ Senior Professor at the Administrative and Financial Law Department, \\ National University of Life and Environmental Sciences of Ukraine \\ E-mail: kovalyeva@gmail.com \\ N.G. SOKOLOVSKA, \\ Legal work management specialist, "KROM» law firm \\ E-mail: natascham171@ukr.net
}

\begin{abstract}
Summary. The article analyzes the current state of ensuring the right to sexual orientation and gender identity, analyzes regulations, examines the statistics of criminal offenses on this issue.

To achieve this goal, an analysis of current legislation on the grounds for criminal liability for violation of the rights to sexual orientation and gender identity, examined the results of court proceedings, identified motives for bias.

It is established that there is no aggravating circumstance for violation of the right to sexual orientation and gender identity in the Criminal Code of Ukraine.

The study showed that the current legislation of Ukraine on criminal liability for violation of the rights to sexual orientation and gender identity does not provide a proper solution to this problem. However, given the need for timely decision-making on this issue, there are reasonable proposals: to expand the list of "protected features» that are subject to protection, in particular criminal law; clearly define sexual orientation and gender identity as "protected traits»; to supplement the list of circumstances that aggravate the punishment provided for in paragraph 3 of Part 1 of Art. 67 of the Criminal Code of Ukraine, the grounds for committing criminal offenses based on hatred of sexual orientation and gender identity; for the correct functioning of the provisions of the Criminal Code of Ukraine, it is necessary to give a clear definition of such phenomena as: «intolerance», "sexual orientation", "gender identity» at the legislative level, which will prevent the abuse of these concepts.
\end{abstract}

Keywords: intolerance, sexual orientation, gender identity, criminal offenses of hatred, protected traits, violations of rights, motives for prejudice

\section{Introduction.}

The article is devoted to the study of ensuring the right to sexual orientation and gender identity, analyzed regula- tions and statistics of criminal offenses on this issue.

In modern conditions of society development, tendencies to individualization of the individual, individual human freedom 
as a basic value in society, the list of human rights has diversified. Sexual orientation and gender identity are beginning to be perceived as human rights. Therefore, this problem is attracting more and more attention from national institutions.

By ratifying the European Convention on Human Rights and Protocol №12 thereto, our state has prohibited discrimination on the grounds of sexual orientation and gender identity. In addition, the European integration processes taking place in all spheres of public life have also assigned a number of tasks to our state, one of which is to ensure the consolidation of the rights of the LGBT community and the rights to gender identity (Protokol № 12 do Konventsii pro zakhyst prav liudyny..., 2000).

At the same time, domestic legal science has not yet developed a thorough study on the nature of the right to sexual orientation and gender identity, its content and boundaries. Given the novelty, the lack of comprehensive research on the rights to sexual orientation and gender identity, the problem of liability for violations of these rights is relevant and requires proper research.

\section{Analysis of recent research and publications.}

There are currently no special comprehensive studies on the current problems of establishing liability for violations of the rights to sexual orientation and gender identity. The right to sexual orientation and gender identity has been studied by legal scholars only in certain aspects and in accordance with the specific objectives of research conducted by scholars in different periods. It was not the subject of a comprehensive thorough study, which led to the lack of generally accepted approaches to the disclosure and solution of this problem. However, the issue of ensuring the rights to sexual orientation and gender identity is reflected in the works of such scholars as O.E. Avramova, O.G. Asmolova, O.V. Batanova, S.M. Breus, D.O. Vovka, V.S. Gerbut, O.R. Dashkovskaya, M.I. Kozyubra, A.M. Kolodiya, T.M. Melnyk, Y.K. Tovpeko and others.

\section{The purpose of the article.}

Establishing the state of modern legislation of Ukraine on criminal liability for violation of the rights to sexual orientation and gender identity. Substantiation of proposals to improve the current criminal legislation on these issues.

\section{Results.}

According to the Constitution of Ukraine, a person, his life and health, honor and dignity, inviolability and security are recognized in Ukraine as the highest social value. Human rights and freedoms and their guarantees determine the content and direction of the state, the state is accountable to man for his activities. The establishment and protection of human rights and freedoms is the main duty of the state (Article 3); everyone has the right to respect for his dignity (Article 28, paragraph 1) (Konstytutsiia Ukrainy, 1996).

The state, fulfilling its main duty - the assertion and protection of human rights and freedoms - must not only refrain from violations or restrictions of human rights and freedoms, but also take appropriate measures to ensure their full realization by all those under its jurisdiction. To this end, the legislator must ensure effective legal regulation and create mechanisms necessary to meet human needs and interests. In view of the above, the state should not only refrain from actions that violate constitutional rights and free- 
doms, but also introduce legislation that would ensure a proper response to the commission of the offense.

One of the main goals of the National Strategy in the field of human rights, approved by the Presidential Decree of August 25, 2015 № 501/2015, is to create an effective system for preventing and combating discrimination. The Criminal Code of Ukraine contains a number of articles in the General (Article 67) and Special Parts (Articles 115, 121, 122, 126, 127, $129,294)$, which provide for more severe punishment for criminal offenses committed on the grounds of racial, national or religious intolerance (which are hate crimes), and Article 161 of the Criminal Code, which establishes criminal liability for inciting national, racial or religious hatred and enmity. Thus, despite the fact that the concept of «hate crime» is absent in Ukrainian law, in fact, this category of crimes is recognized by the legislator, but only for the three reasons mentioned. If the criminal offense was committed on the grounds of intolerance of a person's sexual orientation or gender identity, the current legislation does not provide for a more severe punishment for him, and thus does not recognize it as a «hate crime».

Gender equality is one of the components of the development and formation of democracy. Establishing such equality not only de jure, but also de facto requires overcoming gender stereotypes and ensuring equal distribution of social, political and economic opportunities.

The Council of Europe's Gender Equality Strategy 2018-2023 states that gender equality implies equal rights for women and men, girls and boys, as well as their equal importance, opportunities, responsibilities and participation in all spheres of public and private life. It also means equal access of women and men to resources and the distribution of these resources between them (Stratehiia hendernoi..., 2018).

However, the achievement of these goals is not possible without the development and implementation of appropriate legal regulation at both international and national levels. Legal regulation of gender relations is necessary for their harmonious formation and elimination of shortcomings that can lead to a stereotype of the role of one or another sex in certain spheres of public life.

By signing an Association Agreement with the EU in 2014, Ukraine has committed itself to guaranteeing equal opportunities for women and men in all areas. The values of gender equality and non-discrimination are enshrined in the UN Charter, the UN Sustainable Development Goals, the Beijing Declaration and the Platform for Action.

Ukraine has ratified the Convention on the Elimination of All Forms of Discrimination against Women and its Optional Protocol. There are a number of domestic regulations that focus on gender equality the State Social Program for Equal Rights and Opportunities for Women and Men, the Strategy and Action Plan in the field of human rights, the National Action Plan to implement the UN Security Council resolution. We can summarize that a lot of work has been done in recent years, but the movement for the protection of human rights requires constant progress (Suslova \& Holub, 2019).

The Parliamentary Assembly of the Council of Europe notes that sexual orientation is part of everyone's identity, which includes heterosexual, bisexual and homosexual orientations. The Parliamentary Assembly of the Council of Europe also notes that the latter is not prosecuted in any of the member states of the Council of Europe. The concept of «sexual orientation» from the XX century, increasingly used in 
the context of human rights protection and anti-discrimination. Adoption in 1981 by the Parliamentary Assembly of the Council of Europe of Resolution 756 (1981) on discrimination against homosexuals, which recognized the right to sexual self-determination, as well as the further removal of homosexuality from the list of disorder codes following the 1990 revision of the International Statistical Classification of Diseases and Problems. developed by the World Health Organization have become the starting point for the legal protection of LGBT people against discrimination and harassment ( Tovpeko, 2017). The gradual process of evolution of the content and scope of rights and freedoms towards their expansion in accordance with the level of public life in the spectrum of sexual orientation is currently underway.

Obviously, the process of developing comprehensive anti-discrimination legislation cannot be rapid. However, based on current realities and in the context of intensifying Ukraine 's international cooperation with the European Union, the demand of Ukrainian society to increase the effectiveness of the mechanism for protecting citizens from discrimination, including on the grounds of sexual orientation, is clear (Tovpeko, 2017).

What is a criminal offense based on hatred. These are criminal offenses caused by intolerance of certain groups in society.

Examining the data of the OSCE Office for Democratic Institutions and $\mathrm{Hu}$ man Rights (ODIHR), it can be noted that such criminal offenses have two elements: the action is a criminal offense under criminal law; the motive for a criminal offense is prejudice against a certain group of people.

Motivation by prejudice means that the offender has chosen the object of the criminal offense because of its protected features. A protected trait is a basic trait common to a group of individuals - race, religion, ethnicity, language, sexual orientation or gender identity, and so on.

There is no universal list of protected features in the world. However, for European states, the basis for determining the set of grounds for bias is Article 14 of the European Convention on Human Rights, which is binding on Ukraine (sex, race, color, language, religion, political or other opinion, national or social origin, association with a national minority, property, birth or other status) and Article 21 of the EU Charter of Fundamental Rights (race, color, ethnic or social origin, genetic characteristics, language, religion or belief, political or any other opinion, belonging to a national minorities, property, birth, disability, age or sexual orientation). The case law of the European Court of Human Rights (a body of the Council of Europe of which Ukraine is a member) and the European Court of Justice (an EU body whose practice should be guided in terms of integration with the European Union) is also often used as a guide.

The concept of «hate crime» does not exist in Ukrainian criminal law. An analysis of the Criminal Code reveals that criminal offenses of hatred in Ukraine are intentional acts aimed at inciting national, racial or religious hatred and hatred, humiliating national honor and dignity or insulting the feelings of citizens in connection with their religious beliefs, as well as direct or indirect restriction of citizens' rights on the grounds of race, color, political, religious and other beliefs, sex, ethnic and social origin, property status, place of residence, language or other grounds.

However, in our opinion, the motives of bias that exist in the current criminal law, it would be appropriate to expand, taking into account the experience of European countries. It was Bill 3316 that proposed to expand the list of «grounds for hatred» by 
adding intolerance to a person's sexual orientation or gender identity, and to establish that the motive for hatred should always be an aggravating circumstance.

Criminal offenses committed on the basis of hatred have serious consequences. After all, they not only have a negative impact on each individual victim, but also create a general psychological shock for all who belong to a certain social group. In other words, these criminal offenses are reports that all such people are in danger, are undesirable members of society and should live in fear for their lives, health or property. Remaining unpunished, such criminal offenses create an atmosphere of general fear in society, because, one way or another, everyone belongs to a certain social group, and therefore can potentially become a victim. In addition, the perpetrators who are not brought to justice see in the state's inaction a tacit agreement with the rejection and prejudice against a certain social group, and therefore receive, in our opinion, an unspoken sanction for such offenses. Therefore, the clearer the legislation defines what is a criminal offense of hatred, and the more detailed the protected features, the motives of bias, the more effective will be not only the state penal policy, but also, accordingly, the policy of protection of victims.

Also, the legally defined protected features are the basis for the collection of official statistics on the number of criminal offenses committed on the basis of intolerance.

Meanwhile, Ukrainian criminal law does not establish grounds for prejudice on the grounds of sexual orientation and gender identity.

On April 9, 2020, the Verkhovna Rada introduced Bill № 163316 (On Amendments to the Criminal Code of Ukraine (on Combating Hate Crimes on the Grounds of Sexual Orientation and Gender Identity).
The law proposed criminalizing intolerance, public appeals, and degrading treatment based on sexual orientation or gender identity.

In addition, the bill provided for the introduction of «sexual orientation and gender identity» as an aggravating circumstance in the article of the Criminal Code relating to violence (Articles 67, 115, 120,121,122, 126,127,129, 293, 294 of the Criminal Code). (Proekt Zakonu pro vnesennia zmin do Kryminalnoho kodeksu Ukrainy № 3316, 2020).

The purpose of the draft Law was to improve the provisions of the Criminal Code of Ukraine on the procedure for prosecuting criminal offenses against human life and health, committing intolerance on the grounds of sexual orientation or gender identity.

The draft law proposed to supplement Article 67 of the Criminal Code of Ukraine with such a circumstance that aggravates the punishment for committing a criminal offense on the grounds of sexual orientation of a person or his gender identity. also, it was envisaged that such a feature would become mandatory for the court to take into account in criminal proceedings.

In addition, the bill provided for the addition of Articles 115, 121, 122, 126, 127, 129, 293, and 294 of the Criminal Code of Ukraine with such separate motives for committing relevant criminal offenses as intolerance to sexual orientation (group of persons) or gender identity (Proekt Zakonu pro vnesennia zmin do Kryminalnoho kodeksu Ukrainy № 3316, 2020).

It was envisaged to supplement the Criminal Code of Ukraine with a new Article 161-1 (Public appeals to hostility, violence, persecution or humiliation on the grounds of sexual orientation or gender identity).

However, despite the compliance of the bill with EU law and the Association Agreement, namely: 
- Article 1 p.e of the Association Agreement stipulates that Ukraine and the EU have agreed to strengthen cooperation in the field of justice, freedom and security in order to ensure the rule of law and respect for human rights and fundamental freedoms, as in accordance with Article 2 of Section I of the Agreement, respect for democratic principles, human rights and fundamental freedoms, and respect for the rule of law must form the basis of the domestic and foreign policies of the Parties and are fundamental elements of this Agreement. Also Art. 4 of Chapter II of the Association Agreement stipulates that one of the objectives of the political dialogue between the Parties is to strengthen respect for democratic principles, the rule of law, human rights and fundamental freedoms, including the rights of persons belonging to national minorities, and non-discrimination. minorities, and respect for diversity, as well as contributing to the consolidation of domestic political reforms. In Art. 14 of Chapter III states that in the framework of cooperation in the field of justice, freedom and security, the Parties attach special importance to strengthening the rule of law and strengthening institutions at all levels in the field of governance in general and law enforcement and judicial authorities in particular. Thus, the norms proposed in the bill, which provide for the protection of human rights and punishment for their violation, namely for various manifestations of «intolerance to sexual orientation or gender identity» are in line with the objectives of the Association Agreement.

The provisions of the draft law are in line with Article 10 of the Treaty on the Functioning of the European Union, which states that EU efforts are aimed at combating discrimination based on sex, racial or ethnic origin, religion or belief, (physical or mental) disability, age or sexual orientation;
- Art. 21 of the Charter of Fundamental Rights of the European Union prohibits any discrimination based on sex, race, color, ethnic or social origin, genetic characteristics, language, religion, beliefs, political or other opinion, belonging to a national minority, financial status, origin, incapacity, age or sexual orientation, genders identity.

In their opinion, the available official statistics on criminal offenses on the grounds of sexual orientation and gender identity do not reflect the real state of affairs in this area, and therefore there are no criminal offenses on the above grounds.

After all, the National Contact Point from Ukraine on Hate Crimes contains data only for 2015 and mentions only one case of initiation of criminal proceedings under the article «Hooliganism» on the grounds of sexual orientation and eight cases of criminal offenses under other articles of the Criminal Code , in which the motives of intolerance on this basis are viewed. The annual report of the Parliamentary Commissioner for Human Rights on the state of observance of human and civil rights and freedoms in Ukraine for 2019 states that «since the beginning of 2019, the Commissioner has considered 29 reports of discrimination on the grounds of sexual orientation and gender identity, and opened 28 lawsuits. on this issue.»

It also noted that the results of the Commissioner's monitoring of the rights and freedoms of the LGBT community show that the situation in preventing and combating discrimination on the grounds of sexual orientation and gender identity has not changed significantly compared to previous years (Zvit Upovnovazhenoho VRU z prav liudyny..., 2019). At the same time, in 2019 alone, the experts of the Our World Center recorded more than 320 criminal offenses committed on the 
basis of homophobia, transphobia, discrimination, as well as other violations of LGBT rights in Ukraine. (Zvit za rezultatamy doslidzhennia: Opytuvannia hromadskoi ..., 2019). In the annual «Rainbow Europe» rating on the situation with the protection of gender identity and sexual orientation on the continent, Ukraine ranked 35 th out of 49 . It should be noted that the situation is not better with the investigation of hate crimes based on homophobia or transphobia, gender identity. Investigators ignore these motives in committing criminal offenses, classifying them mostly as ordinary hooliganism or other criminal offense without aggravating circumstances, do not initiate criminal proceedings under Article 161 of the Criminal Code, which is currently the only way to take such motives into account when sentencing.

In January-December 2019, the Prosecutor General's Office of Ukraine registered 184 criminal offenses committed on the grounds of racial, national or religious intolerance, while in 85 cases the criminal proceedings were closed and not brought to court.

According to judicial statistics of Ukraine, in 2019 the number of court cases under Article 161 of the Criminal Code of Ukraine was nine, and the number of persons in court was 10 . Of these, four people were convicted at the end of the year in four cases. Instead, the proceedings in six cases are closed.

A study of the jurisprudence on this issue shows that even when an investigator initiates criminal proceedings under Article 161 of the Criminal Code, it almost never leads to charges under this article in court. The existing criminal legislation, in our opinion, is not adapted for the correct classification of criminal offenses of hatred on any grounds other than «race», «nationality», «religious beliefs».

\section{Conclusions and Prospects.}

The study showed that the current legislation of Ukraine on the definition of liability for violations of the rights to sexual orientation and gender identity does not provide a proper solution to this problem. However, given the need for timely decision-making on this issue, in our opinion, it is appropriate:

expand the list of «protected features» that are subject to protection, including criminal law;

clearly define sexual orientation and gender identity as «protected traits»;

to supplement the list of circumstances that aggravate the punishment provided for in paragraph 3 of Part 1 of Art. 67 of the Criminal Code of Ukraine, the grounds for committing criminal offenses based on hatred of sexual orientation and gender identity;

for the correct functioning of the provisions of the Criminal Code of Ukraine, it is necessary to give a clear definition of such phenomena as: «intolerance», «sexual orientation», «gender identity» at the legislative level, which will prevent the abuse of these concepts.

\section{References}

1. Protokol №12 do Konventsii pro zakhyst prav liudyny y osnovopolozhnykh svobod (2006): Mizhnarodnyi dokument 04.11.2000 № 12. Ofitsiinyi visnyk Ukrainy, 32, 2376: 36909/2006 (in Ukrainian).

2. Konstytutsiia Ukrainy 28.06.1996 №254k/96-VR. Available at: https: //zakon.rada.gov.ua/laws/ show/254\%D0\%BA/ 96-\%D0\%B2\%D1\%80\#Tex 1 (in Ukrainian).

3.Stratehiia hendernoi rivnosti Rady Yevropy na 2018-2023. Available at: https://rm.coe.int/ prems-041318-gbr-gender-equality-strategy2023-ukr-new2/ 16808b35a4 (in Ukrainian).

4. Suslova, I.M. \& Holub, O.A. (2019). Henderna rivnist yak tsyvilizatsiinyi vybir Ukrainy. 
Informatsiina bezpeka liudyny, suspilstva, derzhavy, 2: 152-156 (in Ukrainian).

5. Tovpeko, Ya.K. (2017). Realizatsiia konstytutsiino-pravovykh norm pro prava liudyny shchodo seksualnykh menshyn: porivnialno-pravove doslidzhennia. Kyiv (in Ukrainian).

6. Proekt Zakonu pro vnesennia zmin do Kryminalnoho kodeksu Ukrainy (shchodo protydii zlochynam na hrunti nenavysti za oznakamy seksualnoi oriientatsii ta hendernoi identychnosti) reiestr. № 3316 09.04.2020. Available at: http://w1.c1.rada.gov.ua/pls/zweb2/ webproc4_1?pf3511=68552 (in Ukrainian).
7. Zvit Upovnovazhenoho VRU z prav liudyny. Available at: http://www.ombudsman. gov.ua/files/Dopovidi/zvit\%20za\%2019 (in Ukrainian).

8. Zvit za rezultatamy doslidzhennia: «Opytuvannia hromadskoi dumky dlia vyznachennia suspilnoho spryiniattia LHBT ta shliakhiv yoho polipshennia». Available at: https://gay.org.ua/blog/2020/04/27/ zvit-pro-zlochyny-na-grunti-nenavystiskoieni-za-oznakamy-sohi-v-ukraini-u2019-r-dlia-shchorichnoho-zvitu-bdiplobsie (in Ukrainian).

\section{С.С. Ковальова \& Н.Г. СоколовСьКа (2021). ДО ПИТАННЯ КРИМІНАЛЬНОї ВІДПОВІДАЛЬНОСТІ ЗА ПОРУШЕННЯ ПРАВ НА ГЕНДЕРНУ ІДЕНТИЧНІСТЬ ТА СЕКСУАЛЬНУ ОРІЕНТАЦІЮ. ПравО. ЛюдИНа. ДовкілЛЯ, 12(1): 173-180.} https://doi.org/10.31548/law2021.01.020.

Анотація. У статті аналізується сучасний стан забезпечення права на сексуальну орієнтацію та гендерну ідентичність, проаналізовано нормативно-правові акти, досліджена статистика кримінальних правопорушень із зазначеної проблеми.

Для досягнення поставленої у роботі мети проведено аналіз діючого законодавства щодо підстав встановлення кримінальної відповідальності за порушення прав на сексуальну орієнтацію та гендерну ідентичність, досліджено результати розгляду судових справ, визначено мотиви упередженості .

Встановлено, що обтяжуюча обставина за порушення права на сексуальну орієнтацію та гендерну ідентичність в КК України відсутня.

Проведене дослідження засвідчило, щочинне законодавство України щодовизначення кримінальної відповідальності за порушення прав на сексуальну орієнтацію та гендерну ідентичність не забезпечує належне вирішення цієї проблеми. Проте, зважаючи на необхідність здійснення своєчасного прийняття рішень з цього питання обгрунтовані пропозиції: розширити перелік "захищених ознак», які підлягають охороні, зокрема кримінальним законодавством; чітко визначити сексуальну орієнтацію та гендерну ідентичність як "захищених ознак»; доповнити перелік обставин, які обтяжують покарання, передбачених п. $34.1 \mathrm{~cm} .67$ КК України, підставами скоєння кримінальних правопорушень на грунті ненависті до сексуальної орієнтації та ґендерної ідентичності; для коректного функціонування положень КК України необхідно дати чітке визначення таким явищам, як: "нетерпимість», «сексуальна орієнтація», "гендерна ідентичність» на законодавчому рівні, що унеможливить зловживання даними поняттями.

Ключові слова: нетерпимість, сексуальна орієнтація, гендерна ідентичність, кримінальні правопорушення ненависті, захищені ознаки, порушення прав, мотиви упередження

180 | ISSN 2663-1350 «ПРАВО. ЛЮДИНА. ДОВКІЛЛЯ» | «LAW. HUMAN. ENVIRONMENT» Vol. 12, № 1, 2021 